https://doi.org/10.52058/2786-4952-2022-1(6)-307-317

Попадич Олена Олександрівна доктор педагогічних наук, доцент, доцент кафедри загальної педагогіки та педагогіки вищої школи, Державний вищий навчальний заклад «Ужгородський національний університет», вул. Локоти, 25, м. Ужгород, 88017, тел.: (050) 555-02-21, https://orcid.org/0000-0003-1426-4114

Замрозевич-Шадріна Світлана Романівна доктор педагогічних наук, доцент, доцент кафедри фахових методик і технологій початкової освіти ДВНЗ «Прикарпатський національний університет імені Василя Стефаника», вул. Коновальця 130 А, кв.2, м. Івано-Франківськ, 284000, тел.: (096) 606-81-82, https://orcid.org/0000-0003-0138-3587

\title{
ПСИХОЛОГО-ПЕДАГОГІЧНІ ЗАСАДИ ВПРОВАДЖЕННЯ ІНТЕГРАТИВНИХ КУРСІВ В ОСВІТІ
}

Анотація. У статті представлено на концептуальному рівні критерії оцінки значущості та доцільності інтегративних курсів, їх впровадження та навчально-методичного забезпечення. Показано, що дозволяє не тільки прогнозувати їх якість, але і ефективно здійснювати всі подальші етапи процесу побудови і вдосконалення, а також перевірку і використання в практиці навчання. Концепція інтегративного курсу, як і будь-яка інша концепція, щоб виконувати своє призначення, повинна відповідати ряду вимог. Акцентовано, що навіть якщо концепція вносить нове лише в окремі елементи навчального курсу, необхідно співвідносити ці зміни з всіма іншими компонентами змісту навчання. Обгрунтовано, що інтегративний курс на методологічному рівні доцільно розглядати як єдине ціле 3 появою нової якості за рахунок нових способів зв'язку елементів, які складають його міждисциплінарний зміст. За цих умов світоглядна функція інтегративного курсу передбачає формування в педагога інтегративних методологічних знань. Встановлено, що під час структурування змісту інтегративного курсу необхідно враховувати психологічні аспекти теорії пізнання, максимально використовувати аналогії i асоціації, зокрема віддалені. Визначальним критерієм тут має бути професійна значущість навчального матеріалу. Усвідомленість знань і оволодіння на цій основі відповідними вміннями й навичками вимагає створення особливого психологічного обгрунтування для того, щоб учні мали змогу виявляти активність, ініціативу, мотивувати свої відповіді чи дії. Дотримання вимог міжциклової інтеграції знань посилює мотиваційний аспект у вивченні інтегративних курсів. Визначено, що у структуруванні змісту інтегративних курсів важлива роль належить не тільки 
Журнал«Герспективитаінновації наукиљ

(Серія «Гедагогіка», Серія«ГЕихологія», Серія«Медицина»

№1(6) 2022

дотриманню логіки розгортання міждисциплінарного змісту курсу, психологічній сумісності понять, що вивчаються у рамках інтегративного курсу. Виявлено, що перша вимога у загальному дотримується у побудові конкретних авторських інтегративних курсів, але друга майже завжди порушується. Сформульовано принципи специфічні для кожного з рівнів, що характеризують їх з якісної сторони: цілеспрямування, формування змісту, функціонування та прогнозування інтегративних курсів. Обгрунтовано концептуальні засади проектування інтегративних курсів та розроблено критерії доцільності впровадження інтегративних курсів. Система інтегративних курсів виступає як якісно нова, цілісна система, наділена інтегративними властивостями, що якісно відрізняються від властивостей окремих курсів, що створили цю систему. Відзначено, що основною передумовою формування системи інтегративних курсів $\epsilon$ теоретичне обгрунтування доцільності функціонування кожного окремого курсу та забезпечення координації системи інтегративних курсів 3 предметними навчальними курсами.

Ключові слова: психолого-педагогічні засади, інтегративні курси, освіта, психологічна сумісність, концептуальні засади, проектування, критерії доцільності, впровадження, система інтегративних курсів, міжциклова інтеграція.

Popadych Olena Oleksandrivna Doctor of Pedagogical Sciences, associate professor at the department of general pedagogy and pedagogy of higher education Public higher education institution «Uzhhorod National University, Lokotu St., 25, », Uzhhorod, 88017, tel.: (050) 555-02-21, https://orcid.org/0000-0003-1426-4114

Svitlana Zamrozevych-Shadrina Doctor of Pedagogical Sciences, associate professor at the department of professional methods and technologies of Primary Education Vasyl Stefanyk Precarpathian National University, Ivano-Frankivsk, Konovalets St., 130 A, apt.2, tel.: (096) 606-81-82, https://orcid.org/0000-00030138-3587

\section{PSYCHOLOGICAL AND PEDAGOGICAL FUNDAMENTALS OF THE INTEGRATED COURSE INTRODUCTION IN THE EDUCATIONAL PROCESS}

\footnotetext{
Abstract. The article gives conceptual presentation of the criteria of assessment of the importance and expedience of integrated courses, their introduction in the educational process and educational-methodic supply. It provides the opportunity of not only forecasting their quality, but also effective fulfilment of the next stages of the process of completion and improvement, as well as control and application in the practice of training. To perform its function, the concept of integrated courses, similar to any other concept, should meet some requirements. It 
is stressed that even in case the concept introduces something new into some elements of the educational course, it is necessary to correlate those changes with all other components of the educational content. It is substantiated that methodologically the integrated course should be considered as a single entity with a new quality due to the new means of its elements relations, which create its interdisciplinary content. Under such conditions, the ideological function of the integrated course suggests formation of a teacher of the integrated methodological knowledge. It is determined that to structure the content of the integrated course, it is necessary to consider psychological aspects of the comprehension theory, to maximum use the analogies and associations, particularly distant ones. Therefore, professional significance of the educational material is the crucial criterion. Comprehension of the knowledge and mastering of the appropriate skills need creation of the specific psychological substantiation for pupils to be able to demonstrate activities, initiative, to motivate their answers and actions. Following the requirements of the intercycle integration of knowledge intensifies the motivation aspect in the integrated courses learning. It is confirmed that in structuring the content of integrated courses, a particular attention should be paid not only to the logics of development of the course interdisciplinary content, but also to the psychological compatibility of notions, which are studied within the frames of the integrated course. It is determined that the first requirement is actually followed in the process of developing some authors' integrated courses, whereas the second one is almost always neglected. The work describes the principles, which are specific for each of the levels and characterize their quality, i.e. purposeful nature, focus of the content, performance and forecast of the integrated courses. The article substantiates the conceptual fundamentals of the integrated course projecting and development of the criteria of reasonability of the integrated course introduction. A system of integrated courses is a new quality integral system with the integrated properties, which significantly differ from the features of other courses, making the system. The work notes that the main precondition of formation of a system of integrated courses is the theoretical substantiation of the expedience of each separate course performance and supply of the coordination of the integrated courses system with the subject educational courses\&

Keywords: psychological and pedagogical fundamentals, integrated courses, education, psychological compatibility, conceptual fundamentals, projecting, expedience criteria, introduction, system of integrated courses, intercycle integration.

Постановка проблеми. Підготовка майбутніх учителів у світлі сучасної парадигми полягає у формуванні гуманістичної спрямованості педагогічної діяльності, яка розглядається як професійна властивість, що орієнтована, звернена до учня і відбувається через взаємодію вчителя і школяра. Ці положення можуть бути реалізовані лише за умови ефективного формування професійної компетентності вчителя, яка характеризує рівень його інтеграції у 
інноваційне середовище; передбачає певний відхід від традиційного процесу формування вузького спеціаліста та визначається необхідністю розвитку багатопрофільного фахівця.

Психолого-педагогічні засади, на яких базується концепція інтегративного курсу представляє і обгрунтовує ідею вирішення дидактичних задач, визначених метою курсу та цілями загальної та професійної освіти. Концепція дозволяє об'єктивно визначити реальні можливості конкретного інтегративного курсу та його значущість.

Останнім часом загострилася суперечність між становленням нових суспільних вимог до якостей особистості і сформованими типами шкіл, їхньою структурою, функціями, термінами навчання, навчальними програмами. На жаль, залишилися актуальними i низка суперечностей, виділеним у М. Махмутовим [6] ще кілька десятиліть тому. Це невідповідність між об'єктивно наростаючим об'ємом наукових знань і неможливістю засвоєння системи цих знань учнями у рамках сформованих термінів навчання за єдиними програмами при відсутності внутрішнього зв'язку між навчальними предметами, при вкрай перевантажених програмах і підручниках, зі застарілою логікою викладу навчального матеріалу, яка не відповідає завданням розвитку творчого мислення учнів.

Водночас, «і до змісту, і до процесу навчання відноситься суперечність між необхідністю формування в учнів системи знань і цілісного світогляду, їхньої пізнавальної потреби i мотивів навчання i праці, i відсутності системності у самому предметному викладанні, роз'єднаністю природничих і технічних знань між собою та між ними і гуманітарними дисциплінами, а для професійної школи ще й відсутністю внутрішнього взаємозв'язку між всім циклом загальноосвітніх предметів і циклом дисциплін професійно-технічного циклу, що породжує не тільки дублювання і перевантаження, але і заважає мотивації учіння» $[6$, с.9]. Автори роблять висновок, що сума неупорядкованих знань із різних галузей наук і сформованих засобами масової інформації замість єдиної системи - серйозний недолік професійної освіти, перебороти котрий дослідним, емпіричним шляхом неможливо.

На наш погляд, у першу чергу необхідні критерії оцінки значущості та доцільності конкретних інтегративних курсів, їх впровадження та навчальнометодичного забезпечення. Наявність концепції, що містить відповіді про особливості інтегративного курсу, дозволяє не тільки прогнозувати його якість, але і ефективно здійснювати всі подальші етапи процесу побудови i вдосконалення, а також перевірку і використання в практиці навчання. Виняткове значення має робота 3 єдиною концепцією для конструювання системи інтегративних курсів.

Аналіз останніх досліджень і публікацій. Науковець університету в Торонто М. Фуллан зазначає, що програми підготовки педагога неодмінно мають передбачати інтеграцію університетських занять 3 практикою роботи власне у школі, об'єднання студентів у навчальні групи, співпрацю викладачів 
і вчителів школи, об'єднання шкіл-партнерів. Науковець вважає «партнерство школа-3ВО необхідною умовою вдосконалення фахової підготовки майбутнього спеціаліста й загалом навчально-виховного процесу у школі» $[19$, c.21]. Водночас, X. Тімперлі детально вивчала питання підготовки майбутніх педагогів до ефективної фахової діяльності та взаємозалежності ступеня відповідальності педагога за навчальні результати учнів. Дослідниця пов'язує рівень відповідальності педагога 3 остаточними досягненнями учнів, а ключовим чинником вважає мотивацію двох суб'єктів навчання. Не менш істотним принципом навчання науковиця вважає інтеграцію знань та вмінь учнів, що поглиблює педагогічні практики навчання, ефективно змінюючи якість навчання на практиці [10].

Підготовці вчителя присвячена низка праць теоретико-методологічного характеру, зокрема це теоретичні та методичні засади підготовки майбутніх учителів початкової школи до застосування інтерактивної технології (О. Комар [4]), педагогічне моделювання як складова фахової готовності вчителя початкових класів (Н. Бахмат [1]), формування готовності майбутніх учителів до розв'язання типових задач професійної діяльності (Т. Тесленко [9]), готовність майбутніх учителів до організації інтерактивної навчальної взаємодії учнів (Н. Лазаренко [5]) та ін. Інтеграційні процеси в професійній освіті грунтовно досліджувалися у працях Ю. Козловського [3]. Водночас, питання розробки психолого-педагогічних аспектів побудови концепцій впровадження інтегративних курсів в освіті не було предметом спеціального дослідження.

Мета статті полягає у розробленні психолого-педагогічного забезпечення концептуальних засад та критеріїв доцільності впровадження інтегративних курсів у професійній підготовці педагога.

Виклад основного матеріалу. Концепція інтегративного курсу, як i будь-яка інша концепція, щоб виконувати своє призначення, повинна відповідати ряду вимог. Навіть якщо концепція вносить нове лише в окремі елементи навчального курсу, необхідно співвіднести його з всіма іншими компонентами змісту навчання, охарактеризувати зміни, які зазнає ця система.

Оскільки концепція трактується у сучасній науці як система поглядів на певне явище чи об'єкт (інтегративний курс), то розглянемо перш за все компоненти такої системи: навчальний предмет, навчальний курс, інтегративний курс тощо. У більшості навчальних закладів одночасно ведеться професійна підготовка (процес отримання знань, умінь і навичок в системі професійної освіти, необхідних для здійснення того або іншого виду професійної діяльності) та загальноосвітня підготовка (підготовка учнів за загальноосвітньою програмою, спрямованою на розв'язання завдань формування загальної культури особистості, адаптації особистості до життя в суспільстві, на створення основи для усвідомленого вибору і освоєння професійних освітніх програм). 
Журнал«Герспективитаіновації наукиљ

(Серія «Гедагогіка», Серія«ГЕихологія», Серія«Медицина»

№1(6) 2022

Навчальний предмет розглядають як галузь знання, адаптовану для цілей освіти. Проведений аналіз поняття “навчальний предмет”, різних класифікацій навчальних предметів (за співвідношенням з наукою, за їх відношенням до виробництва та техніки, за елементами людської культури, за функціями), видів змісту навчального предмета та його структури й джерел формування змісту, а також аналіз понять "навчальний предмет" та "навчальна дисципліна" підводять до висновку про інтегративну природу більшості галузей знань, відповідно, до думки, що практично усі навчальні предмети тією чи іншою мірою $є$ інтегровані.

Проблема полягає у виявленні закономірностей та випадковостей інтегративного підходу у формуванні змісту навчального предмета, у розробленні науково обгрунтованих навчальних предметів 3 оптимальним ступенем інтеграції змісту, форм, методів та засобів.

У педагогічній теорії щодо інтегративних курсів спостерігається відрив наукових досліджень від практики, різнобій теоретичних концепцій інтегративного навчання, практична відсутність наукових критеріїв оцінки існуючих інтегративних курсів тощо.

На думку Ю. Сьоміна, «формальна роз'єднаність споріднених дисциплін в навчальних планах, невиправдані розходження в поняттєво-термінологічному апараті, слабке використання міжпредметних зв'язків в навчальному процесі призводить до того, що синтез навчальної інформації, що транслюється стихійно, покладається на самих студентів, і якщо навіть вони його застосовують, то ефект виявляється незначним» [8, с.20]. Яскравим прикладом такої ситуації є масова поява навчальних курсів, які називають інтегрованими, і котрі часто є лише еклектичним накопиченням різнопредметних знань.

Тому інтегративний курс на методологічному рівні розглядаємо як єдине ціле з появою нової якості за рахунок нового способу зв'язку елементів, які складають його міждисциплінарний зміст. Світоглядна функція інтегративного курсу передбачає формування в учнів інтегративних методологічних знань,

Психологічними передумовами інтегративних курсів, , можуть слугувати розроблені в роботах А. Дьоміна положення про домінуюче інтегроване поняття. Серед численних закономірностей інтеграції знань доцільно виділити декілька незалежних між собою закономірностей: ці дослідження дають можливість сформулювати деякі психологічні закономірності інтеграції знань [2], виходячи з класичних закономірностей педагогіки та психології.

На нашу думку, при побудові інтегративних курсів доцільно спиратися на ці закономірності, а саме розвиток мислення з використанням оптимально поєднаних предметних та інтегрованих знань сприяє розвитку особистості; відтворення необхідних знань за інтегративного підходу до навчання відбувається швидше та повніше, як і перенос засвоєних прийомів діяльності 3 одного навчального предмета в інший, з навчальної діяльності у ненавчальну тощо; функціонування інтелектуальних операцій у сфері інтегрованих знань 
має більшу кількість зв’язків і веде до розвитку мислення; переструктурування ситуацій відбувається швидше та більш умотивовано за умови використання не лише предметних, але й інтегрованих знань; інтеграція знань сприяє розробці прогностичних аспектів мислення, оскільки базується на міждисциплінарних асоціаціях.

Під час структурування змісту інтегративного курсу необхідно враховувати (особливо при відборі ключових понять) психологічні аспекти теорії пізнання, максимально використовувати аналогії і асоціації, зокрема віддалені. Визначальним критерієм тут має бути професійна значущість навчального матеріалу. Усвідомленість знань і оволодіння на цій основі відповідними вміннями й навичками вимагає створення особливого психологічного обгрунтування для того, щоб учні мали змогу виявляти активність, ініціативу, мотивувати свої відповіді чи дії. Процес засвоєння й оволодіння прийомами фахової діяльності повинен бути свідомим і активним, окресленим певною теоретичною і практичною самостійністю.

Виходячи 3 того, що більшість інтегративних курсів має різноцикловий характер, то їх повноцінне засвоєння вимагає одночасного оволодіння змістом чи методами принаймні двох-трьох наук чи галузей знань. Дотримання вимог міжциклової інтеграції знань посилює мотиваційний аспект у вивченні інтегративних курсів. Окрім загальновідомих дидактичних переваг (зокрема, це ущільнення i концентрація навчального матеріалу, що усуває перевантаження учнів і приводять до економії навчального часу) за належного психологічного забезпечення значно підсилюється мотивація вивчення загальноосвітніх дисциплін шляхом показу їх ролі у реалізації суто професійних інтересів учнів.

У структуруванні змісту інтегративних курсів важлива роль належить не тільки дотриманню логіки розгортання міждисциплінарного змісту курсу, але й достатня увага повинна приділятися психологічній сумісності понять, що вивчаються у рамках інтегративного курсу. Зауважимо, що, якщо перша вимога у загальному дотримується у побудові конкретних авторських інтегративних курсів, то друга майже завжди порушується.

Для моделювання структури інтегративних курсів ми вважаємо за доцільне використати основи структурного методу, грунтовно описаного в роботі [7, с.51-56]. У структурному методі дослідження об'єктів відбувається 3 точки зору цілісності. Інші наукові методи, зокрема системний, теж намагаються осягнути цілісність. Логіка побудови інтегрованих курсів буде різною, залежно від точки зору на навчальні дисципліни: чи як на результат розвитку тієї чи іншої галузі знань; чи як на процес наукового мислення. Наступним етапом є моделювання функціональних характеристик та дієвості інтегративного курсу, його змісту інтегративного курсу. Ця проблема є більш вузькою, що дає підставу вважати такі інтегративні курси моделями відповідних інтегративних наук. 
Журнал«Герспективитаінновації наукиљ

(Серія«Гердагогіка», Серія«ПЕихологія», Серія«Медицина»

№1(6) 2022

На основі інтегративного курсу учні дістають уявлення про відповідну науку, так само як за допомогою моделі дослідник розкриває невідомі закономірності досліджуваного об'єкта або явища.

Нами сформульовано концептуальні засади проектування

\section{інтегративних курсів:}

-впровадження інтегративних курсів спрямовано на забезпечення цілісного підходу до загальноосвітньої та професійної підготовки учнів;

- інтегративні курси передбачають формування принципово нового змісту освіти, визначення цілей кожного 3 курсів згідно 3 загальними цілями професійної підготовки;

- основне завдання інтегративних курсів полягає у забезпеченні єдності формування професійних знань та умінь на базі системи фундаментальних знань;

- основу проектування інтегративних курсів складає ідея щодо цілісної інтеграції цілей, змісту, форм, методів та засобів у межах такого курсу;

-інтегративні курси доцільно проектувати на основі їх класифікацій за різними ознаками (змістом, формами, складністю тощо) 3 урахуванням конкретних цілей кожного 3 таких курсів;

•у навчальний процес доцільно включати не поодинокі інтегративні курси, а систему органічно пов'язаних між собою інтегративних курсів, підпорядкованих спільній меті і узгоджених з предметними курсами у даному навчальному закладі;

•кількість та обсяг інтегративних курсів у навчальному залежить від складності та характеру майбутньої професій, специфіки змісту дисциплін;

•кожен інтегративний курс має власну конкретну мету та завдання, однак, разом $з$ тим є складовою частиною змісту професійної освіти;

-для кожного інтегративного курсу визначаються різні терміни навчання, залежно від складності професії, освіти, кваліфікації.

Впровадження інтегративних курсів передбачає також нові підходи до методичного забезпечення навчального процесу. На основі концептуальних засад розроблено критерії доцільності впровадження інтегративних курсів:

-доцільність функціонування кожного конкретного інтегративного курсу відповідно до соціальних запитів та його дидактична завершеність;

• забезпечення педагогічних кадрів для викладання інтегративного курсу із врахуванням його особливостей;

-мотивація та врахування попиту на конкретний інтегративними курс;

•гнучкість, варіативність і диференціація змісту, форм та методів навчання інтегративного курсу;

•наступність у системі інтегративних курсів та можливість взаємодії 3 предметними курсами;

-адаптивність інтегративних курсів в системі змісту професійної освіти.

Насамкінець, виділимо ще деякі важливі характеристики інтегративних курсів: місце інтегративного курсу в системі освіти; мета вивчення 
інтегративного курсу; термін вивчення інтегративного курсу; зміст інтегративного курсу та його науково-методичне та матеріально-технічне забезпечення, а також прогнозування розвитку інтегративного курсу у конкретній педагогічній системі. Якщо розглядати педагогічну систему як гіперсистему, то іiі ієрархічними підсистемами можна вважати систему усіх навчальних курсів, систему інтегративних курсів та інтегративний курс як найменшу з названих підсистем. Особливості системного підходу в контексті побудови інтегративних курсів та виділено основні принципи системного підходу до інтегративних курсів як об’єктів педагогічного дослідження.

Система інтегративних курсів функціонує, якщо їі внутрішні зв'язки, тобто інтегративні курси як такі, міцніші за зовнішні, тобто зв'язки між цими курсами. Для того, щоб система інтегративних курсів існувала мала емерджентні властивості, необхідно, перш за все, забезпечити стійкі внутрішні зв’язки всередині кожного інтегративного курсу зокрема. Якщо ж ця умова не виконується, то маємо або сукупність окремих інтегративних курсів, або ж ці курси у різних поєднаннях входять у інші системи.

Висновки. Перебудова одного з інтегративних курсів вимагає відповідних змін (більш чи менш масштабних) у всіх інших інтегративних курсах, а також виявлення впливу проведених змін на педагогічну систему в цілому. Основною передумовою формування системи інтегративних курсів $€$ теоретичне обгрунтування доцільності функціонування кожного окремого курсу, з одного боку, забезпечення координації системи інтегративних курсів 3 предметними навчальними курсами. Інтегративні та предметні курси, своєю чергою, мають формувати цілісну гіперсистему усіх навчальних курсів конкретного типу навчального закладу. Оптимізація системи інтегративних курсів у професійній освіті - це процес вибору найкращого варіанту співвідношення теоретичного обгрунтованих інтегративних курсів між собою та з педагогічною гіперсистемою. Система інтегративних курсів виступає як якісно нова, цілісна система, наділена інтегративними властивостями, що якісно відрізняються від властивостей окремих курсів, що створили цю систему. Інтегративний курс розглядається у цій системі двояко. 3 одного боку він сам по собі $\epsilon$ інтегративним утворенням, а 3 другого - елементом системи інтегративних курсів.

Інтегративні курси повинні бути орієнтовані на застосування всіх навчальних середовищ, 3 використанням інформаційних технологій. Комп'ютерна версія інтегративного курсу повинна містити його зміст та всі методичні та лабораторно-практичні матеріали. Її особливістю є можливість використання мультимедіа i оперативного звертання учнів необхідними роз'ясненнями за допомогою гіперпосилань з будь-якої предметної області. У професійній освіті особливого значення набуває проведення досліджень на реальних динамічних об'єктах та імітаційних моделях.

До подальших напрямів відносимо дослідження складу інтегративного навчального комп'ютерного курсу та аналіз відповідного програмного забезпечення. 


\section{Jimepamypa:}

1. Бахмат Н. В. Педагогічне моделювання як складова фахової готовності вчителя початкових класів. Педагогічна освіта: теорія і практика. 2011. Вип. 7. С. 14-20.

2. Дьомін А., Угринюк М., Блозва І. Проблемне заняття в коледжі з використанням домінантного інтегруючого поняття. Педагогіка і психологія професійної освіти. 2000. № 2. C. $117-124$.

3. Козловський Ю. М. Інтеграційні процеси в професійній освіті: методологія, теорія, методики: монографія. Львів: Видавництво Львівської політехніки, 2018. 420 с

4. Комар О. А. Теоретичні та методичні засади підготовки майбутніх учителів початкової школи до застосування інтерактивної технології: дис. ... д-ра пед. наук. Умань, 2011. 512 с.

5. Лазаренко Н. I. Тенденції професійної підготовки вчителя в педагогічних університетах України в умовах Євроінтеграції. Автореф. дис д-ра п. н. : 13.00.04/ Iн-т педагогічної освіти та освіти дорослих ім. Івана Зязюна. К., 2020. 40 с

6. Махмутов М., Артемьева Л. Вопросы интегративного потенциала дидактики. Проблемы интеграчии процесса обучения. М., 1989. С.4-44

7. Музиченко В., Повторєва С. Філософські засади структурного методу пізнання. Філософські пошуки. 1997. Вип.1-2. С. 51-56.

8. Семин Ю. Н. Интеграция содержания профессионального образования. Педагогика. 2001. № 2. С.20-25

9. Тесленко Т. В. Формування готовності майбутніх учителів початкової школи до розв’язання типових задач професійної діяльності. Автореф. дис. к.п.н. 13.00.04. ДВНЗ «Прикарпатський національний університет імені Василя Стефаника». Івано-Франківськ. 2017. 25. c

10. Fullan M. The new meaning of educational change (third edition). Toronto, Ontario: Irwin Publishing, 2001. P. 246-247.

11. Timperley H. Teacher professional learning and development. Educational practices series 18. International Academy of Education, International Bureau of Education, 2008. 31 p.

\section{References:}

1. Bahmat, N. V. (2011). Pedagogichne modeljuvannja jak skladova fahovoï gotovnosti vchitelja pochatkovih klasiv [Pedagogical modeling as a component of professional readiness of primary school teachers]. Pedagogichna osvita: teorija i praktika - Pedagogical education: theory and practice, 7, 14-20 [in Ukrainian].

2. D'omin, A., Ugrinjuk, M., Blozva, I. (2000). Problemne zanjattja v koledzhi z vikoristannjam dominantnogo integrujuchogo ponjattja [Problem class in college using the dominant integrative concept]. Pedagogika i psihologija profesijnoï osviti - Pedagogy and psychology of vocational education, 2, 117-124 [in Ukrainian].

3. Kozlovs'kij, Ju. M. (2018). Integracijni procesi v profesijnij osviti: metodologija, teorija, metodiki [Integration processes in vocational education: methodology, theory, techniques]. L'viv: Vidavnictvo L'vivs'koï politehniki [in Ukrainian].

4. Komar, O. A. (2011). Teoretichni ta metodichni zasadi pidgotovki majbutnih uchiteliv pochatkovoï shkoli do zastosuvannja interaktivnoï tehnologiï [Theoretical and methodical principles of preparation of future primary school teachers for the use of interactive technology]. Doctor's thesis. Sumy: SumDU [in Ukrainian].

5. Lazarenko, N. I. (2020). Tendenciï profesijnoï pidgotovki vchitelja v pedagogichnih universitetah Ukraïni $\mathrm{v}$ umovah Evrointegraciï [Trends in teacher training in pedagogical universities of Ukraine in terms of European integration].Extended abstract of Doctor's thesis. Kiev: In-t pedagogichnoï osviti ta osviti doroslih im. Ivana Zjazjuna [in Ukrainian]. 
6. Mahmutov, M., Artem'eva, L. (1989). Voprosy integrativnogo potenciala didaktiki. Problemy integracii processa obuchenija [Questions of integrative potential of didactics. Problems of integration of the learning process]. M. [in Russian].

7. Muzichenko, V., Povtoreva, S. (1997). Filosofs'ki zasadi strukturnogo metodu piznannja [Philosophical principles of the structural method of cognition]. Filosofs'ki poshuki - Philosophical research, 1-2, 51-56 [in Ukrainian].

8. Semin, Ju. N. (2001). Integracija soderzhanija professional'nogo obrazovanija [Integration of the content of vocational education]. Pedagogika - Pedagogy, 2, 20-25 [in Ukrainian].

9. Teslenko, T. V. (2017). Formuvannja gotovnosti majbutnih uchiteliv pochatkovoï shkoli do rozv'jazannja tipovih zadach profesijnoï dijal'nosti [Formation of readiness of future primary school teachers to solve typical problems of professional activity]. Extended abstract of candidate's thesis. Ivano-Frankivs'k: DVNZ «Prikarpats'kij nacional'nij universitet imeni Vasilja Stefanika». Ivano-Frankivs'k [in Ukrainian].

10. Fullan M. The new meaning of educational change (third edition). Toronto, Ontario: Irwin Publishing, 2001. P. 246-247.

11. Timperley H. Teacher professional learning and development. Educational practices series18. International Academy of Education, International Bureau of Education, 2008. 31 p. 